\title{
Viral Antibodies in Diabetes Mellitus
}

\author{
D. R. GAMBLE,* M.B., M.C.PATH., DIP.BACT. ; M. L. KINSLEY,† F.I.M.L.T. ; M. G. FITzGERALD, $\ddagger$ M.D., F.R.C.P. \\ R. BOLTON,§ M.B., F.R.C.P. ; K. W. TAYLOR, $\|$ M.D., PH.D.
}

British Medical fournal, 1969, 3, 627-630

\begin{abstract}
Summary : Sera from 123 patients with diabetes mellitus $\checkmark$ of recent onset, 155 patients with diabetes of more than two years' duration, and 250 normal persons were collected over a period of two and a half years. All sera were tested for neutralizing antibody to Coxsackie virus types B1-6, and a sample was tested for complementfixing antibody to a number of viral, rickettsial, and mycoplasmal antigens.

In diabetics of recent onset no evidence was found of any excess of antibodies to mumps virus or some common respiratory viruses. Insulin-dependent diabetes within three months of onset were found to have higher antibody titres to Coxsackie B virus, particularly of type B4, than either normal subjects or patients with diabetes of longer duration.
\end{abstract}

\section{Introduction}

It has been suggested that infections may sometimes precipitate diabetes mellitus in patients in whom an underlying metabolic defect is present (Adams, 1926 ; Danowski, 1957), but there is mounting evidence of the ability of certain viruses to cause diabetes by producing a pancreatitis-presumably through direct action on the insulin-forming cells.

Diabetes following foot and mouth disease has been reported in cattle, and on one occasion in a goat (Barboni and Manocchio, 1962). Craighead and McLane (1968) described the introduction of diabetes in a proportion of mice inoculated with a neurotropic variant of encephalomyocarditis virus. This strain induced focal lesions in the islet tissue with degranulation of the beta cells; when cortisone was given during the infection the islet tissue underwent extensive necrosis. Another strain of encephalomyocarditis virus adapted to grow in heart muscle caused necrosis of the acinar cells of infected mice but spared the islet tissue (Craighead, 1966). The effect of virus infection on the pancreas may therefore depend both on virus variation and on host factors such as hormonal conditions. A number of viruses may cause inflammatory lesions in the pancreas without necessarily causing diabetes; of these, Coxsackie B virus (Pappenheimer, Kunz, and Richardson, 1951), reovirus (Stanley, Dorman, and Ponsford, 1953), foot and mouth disease virus (Platt, 1956), and mouse hepatitis virus (Hirano and Ruebner, 1968) affect mice, and infectious pancreatic necrosis virus affects fish (Wood, Snieszko, and Yasutake, 1955).

In man, diabetes following mumps was reported by Stang in 1864, and others have since repeated this observation ; in some cases the appearance of diabetes has coincided with a mumps pancreatitis. Other instances of viral pancreatitis probably occur, but there is no record of their being followed by diabetes. Wislocki (1966) reported a case of infectious mono-

\footnotetext{
* Director, Public Health Laboratory at West Park Hospital, Epsom, Surrey.

† Chief Technician, Area Laboratory at West Park Hospital, Epsom, Surrey. Present address : Department of Epidemiology and Health, McGill University, Montreal, P.Q., Canada.

‡ Consultant Physician, the General Hospital, Birmingham 4.

Consultant Physician, Epsom District Hospital, Epsom, Surrey. II Clinical Assistant, Diabetic Department, King's College Hospital,
London S.E.5.
}

nucleosis with pancreatitis. Coxsackie $B$ virus infection of the newborn may induce a focal myocarditis, meningoencephalitis, and sometimes pancreatitis. Kibrick and Benirschke (1956, 1958) reported two such cases of Coxsackie B4 virus infection with necrotic lesions of the pancreas, and Fechner, Smith, and Middelkamp (1963) isolated Coxsackie B4 virus from the pancreas in another. Murphy and Simmul (1964) reported the isolation of Coxsackie B4 virus from an adult with acute pancreatitis and a rising neutralizing antibody titre to this virus during convalescence. We have seen another case, in a 28-year-old woman in whom the Coxsackie B4 neutralizing antibody titre rose from $1: 512$ to $1: 1,024$ during the illness (Gamble, unpublished data).

It therefore seems possible that viral infection plays some part in the aetiology of diabetes in man, particularly in juvenile cases of sudden onset. We have therefore compared antibody titres to a number of common viruses in patients with diabetes of recent onset and those in non-diabetic subjects.

\section{Methods}

During the two and a half years from January 1966 to June 1968123 serum specimens were obtained from patients with diabetes of recent and abrupt onset at three centres (King's College Hospital, London S.E.5 ; Epsom District Hospital, Epsom, Surrey ; and the General Hospital, Birmingham 4). Most of the patients showed ketosis and required insulin treatment from the outset, but at one centre (Epsom) patients with non-insulin-dependent diabetes of abrupt onset were also included.

The precise matching of controls presented difficulties, but for comparison sera were obtained from 155 patients with diabetes of more than two years' duration and from 250 healthy "controls" who had no history of active or recent infection. Table I gives details of origin of the specimens examined.

All the virological tests were done in one laboratory (Epsom). Complement fixation tests were done in plastic trays by the method of Bradstreet and Taylor (1962). Coxsackie virus group A antigens were prepared by the subcutaneous inoculation of suckling mice within 24 hours of birth with prototype virus strains; when mice developed paralysis they were killed and eviscerated, and the carcasses ground in three times their own volume of saline. Group B antigens were prepared from infected primary rhesus monkey kidney tissue cultures; the cells were frozen and thawed three times when they showed widespread cytopathic effect. All Coxsackie antigens were clarified by centrifugation at 5,000 r.p.m. for 30 minutes at $4^{\circ} \mathrm{C}$. and stored at $-20^{\circ} \mathrm{C}$.

Seven Coxsackie virus antigens were included in the range of antigens tested, comprising types A2, A5, A10, A16, B3, $\mathrm{B} 4$, and B5, all of which were known to be prevalent at that time. Since the complement-fixing antibody response in Coxsackie virus infection is often non-specific (Melnick, Wenner, and Rosen, 1964), sera were counted positive for a Coxsackie group if they fixed complement at a dilution of $1: 5$ with antigen of any tested type in that group. 
All other complement-fixing antigens were kindly supplied by Dr. C. M. P. Bradstreet, of the Standards Laboratory, Central Public Health Laboratory, London N.W.9 ; sera were tested at a dilution of 1:20 against these antigens.

Neutralizing antibodies to the Coxsackie B viruses were estimated in primary rhesus monkey kidney tissue cultures. Virus-serum mixtures were prepared in Hanks's tissue-culture maintenance medium, and doubling dilutions of serum were mixed with equal volumes of a virus dilution containing 200 $\mathrm{TCD}_{50}$ of virus per $0.1 \mathrm{ml}$. The mixtures were held at room temperature for one hour before inoculation of two tissueculture tubes per dilution with $0.1 \mathrm{ml}$. Virus titrations were included with each batch to ensure that the virus dose was between 32 and $320 \mathrm{TCD}_{50}$. The sera were titrated in batches comprising a mixture of diabetic and control sera.

\section{Results}

Sera collected up to April 1967 were tested by complement fixation against a variety of viral, rickettsial, and mycoplasmal antigens. The diabetic group comprised sera from 47 patients with recent diabetes. In view of the transitory nature of the complement-fixing antibody response 20 patients with diabetes of more than two years' duration were included with 94 normal subjects in the control group.

The proportion positive against most of the antigens tested was similar in diabetic and control groups (Table II). Significant differences were obtained for influenza C, para- influenza, and Coxsackie $B$ viruses. Influenza $C$ and parainfluenza virus antibodies were more often present in controls than in diabetics, but it was found that the majority of positive control sera were collected from clusters of patients, and localized outbreaks of infection could therefore account for the differences found. On the other hand, there was no such explanation for the excess of diabetic patients with antibody to Coxsackie $B$ virus who came from all areas and were not restricted to any one period of time. Control sera for this period were poorly matched, though most were deliberately collected in the first quarter of the year immediately after the enterovirus season and during the period of maximum incidence of respiratory infection. The frequent occurrence of Coxsackie $\mathrm{B}$ antibodies in diabetics, though inconclusive, was of interest in view of the association of Coxsackie $B$ virus infection with pancreatitis in man and mice. Further specimens were therefore collected in 1967-8. Because of technical difficulties in the production of Coxsackie complement-fixing antigens, poor reproducibility of the tests, and lack of specificity, all subsequent tests were for neutralizing antibody only.

\section{Coxsackie B Virus Neutralizing Antibody Titres}

All serum samples were titrated for neutralizing antibodies to Coxsackie virus types B1-6. A preliminary analysis of geometric mean titres (Fig. 1) showed that diabetics had higher titres against type B4 than normal controls, and that these titres were apparently inversely related to the duration of

TABle I.-Details of Patients

\begin{tabular}{|c|c|c|c|c|c|c|c|c|c|c|c|}
\hline \multirow{3}{*}{ Age } & \multicolumn{4}{|c|}{1966} & \multicolumn{4}{|c|}{1967} & \multicolumn{2}{|c|}{1968} & \multirow{3}{*}{ Tota } \\
\hline & J.-M. & A.-J. & J.-S. & O.-D. & J.-M. & A.-J. & J.-S. & O.-D. & J.-M. & A.-J. & \\
\hline & $\mathrm{K} \mathrm{B} \mathrm{E}^{*}$ & K B E & K $\quad B \quad E$ & K B E & $\begin{array}{lll}\text { K } & B & E\end{array}$ & K $B \quad E$ & K B E & $\begin{array}{lll}K & B & E\end{array}$ & K B E & $\begin{array}{lll}\text { K } & B & E\end{array}$ & \\
\hline $\begin{array}{r}0-19 \\
20-39 \\
40-59 \\
60-\end{array}$ & $\begin{array}{l}6== \\
3= \\
1= \pm\end{array}$ & $\frac{2}{1}=$ 二 & $\begin{array}{l}1 \\
-\end{array}=$ & $\begin{array}{l}53= \\
54= \\
12=\end{array}$ & $\begin{array}{r}\text { New } L \\
1=\quad 5 \\
-3=\quad 2 \\
--\quad 1\end{array}$ & $\begin{array}{l}\text { betics } \\
21= \\
2 \\
2\end{array}$ & $\begin{array}{lll}3 & 2 & 1 \\
1 & 5 & 2 \\
1 & - & 3 \\
- & - & 1\end{array}$ & $\begin{array}{lll}2 & - & \\
2 & 5 \\
6 & -3 \\
6 & 4\end{array}$ & $\begin{array}{l}\text { 三ニ } \\
\text { 三ニ } \\
3\end{array}$ & $\begin{array}{ll}= \pm & 1 \\
\bar{Z} & 1 \\
& 6\end{array}$ & $\begin{array}{l}34 \\
43 \\
25 \\
21\end{array}$ \\
\hline Total & $10--$ & $3--$ & $1--$ & $137-$ & $4-11$ & $42-$ & $\begin{array}{lll}5 & 7 & 7\end{array}$ & $\begin{array}{lll}14 \quad 5 & 11\end{array}$ & --9 & --10 & 123 \\
\hline $\begin{array}{r}0-19 \\
20-39 \\
40-59 \\
60-\end{array}$ & $\begin{array}{l}\text { ニニニ } \\
\text { ニニニ }\end{array}$ & $\begin{array}{l}\text { ニニ二 } \\
\text { ニニ }\end{array}$ & $\begin{array}{l}\text { ニニ二 } \\
\text { ニ }\end{array}$ & $\begin{array}{l}\text { Long-stan } \\
=-二 \\
=-二 \\
=-二\end{array}$ & $\begin{array}{c}\text { ig Diabetics } \\
5=7 \\
2=- \\
3=-\end{array}$ & $\begin{array}{c}\text { More than } \\
1=- \\
= \pm-\end{array}$ & $\begin{array}{l}\text { Years) } \\
\underline{1}=\frac{1}{1} \\
= \pm\end{array}$ & $\begin{array}{rrr}9 & 3 & 2 \\
13 & 19 & 7 \\
7 & 13 & 15 \\
8 & 9 & 23\end{array}$ & $\begin{array}{l}\overline{1} \\
\underline{-} \\
=\end{array}$ & $\begin{array}{l}\text { ニニ二 } \\
\text { ニニ }\end{array}$ & $\begin{array}{l}22 \\
50 \\
38 \\
45\end{array}$ \\
\hline Total & --- & --- & $-\cdots$ & --- & $10-10$ & $1--$ & $1-2$ & 374447 & $1-2$ & --- & 155 \\
\hline $\begin{array}{r}0-19 \\
20-39 \\
40-59 \\
60-\end{array}$ & $\begin{array}{l}\text { 二ニ } \\
\text { 二 } \\
\text { 二 } \\
1\end{array}$ & $\begin{array}{l}\text { ニニ二 } \\
\text { ニニ二 }\end{array}$ & $\begin{array}{l}\text { ニニ二 } \\
\text { 二ニ二 }\end{array}$ & $\begin{array}{l}\text { 二ニ } \\
\text { 二 } \\
\end{array}$ & $\begin{array}{r}\text { Norma } \\
1=18 \\
8=36 \\
-二\end{array}$ & $\begin{array}{l}\text { Sontrols } \dagger \\
=-\frac{6}{6} \\
= \pm 16 \\
\end{array}$ & $\begin{array}{l}\text { ニニニ } \\
\text { ニニ }\end{array}$ & $\begin{array}{l}二=10 \\
二=20 \\
=-20\end{array}$ & $\begin{array}{l}\text { ニニ二 } \\
\text { 二 }\end{array}$ & $\begin{array}{l}=-15 \\
= \pm 20 \\
= \pm 20\end{array}$ & $\begin{array}{l}50 \\
92 \\
59 \\
49\end{array}$ \\
\hline Total & --8 & $\cdots-$ & --- & --2 & $9 \quad 54$ & -31 & $-\cdots$ & --71 & $-\cdots$ & --75 & 250 \\
\hline
\end{tabular}

* K= King's College Hospital, London S.E.5. B = The General Hospital, Birmingham 4. E=Epsom District Hospital, Epsom, Surrey

The norm

Note: All sera were tested for Coxsackie B virus neutralizing antibody. Sera collected up to April 1967 were tested by complement fixation test (excluding two diabetic sera which were anticomplementary).

TABle II.-Proportion of Sera Positive by Complement Fixation Test*

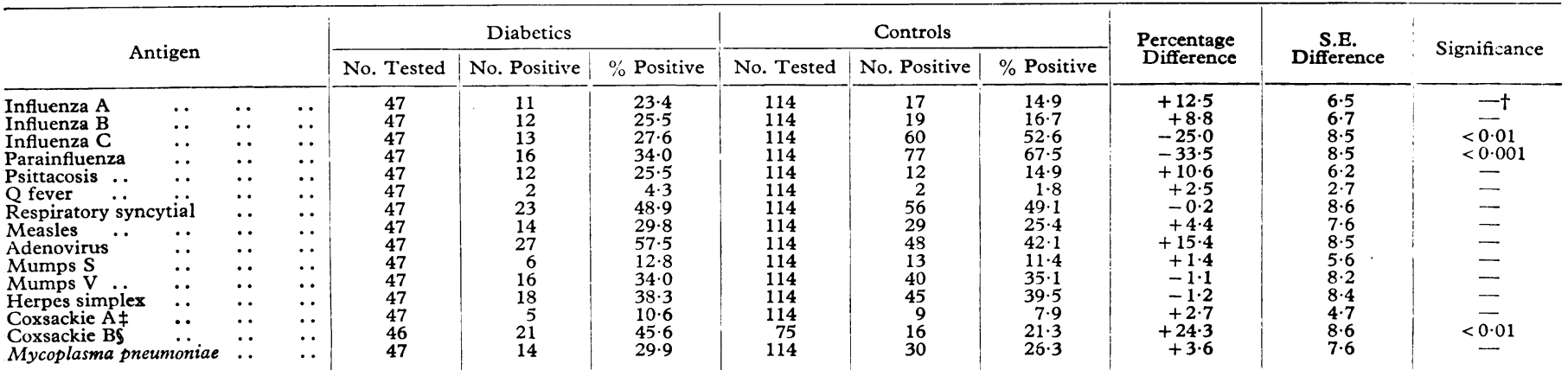

* Titre $\geqslant 1: 5$ against Coxsackie virus antigens; titre $\geqslant 1: 20$ against other antigens. $\dagger-=$ Not significant at $5 \%$ level. $\neq$ Sera reacting with antigens of Coxsackie $A$ type $2,5,10$, or 16 . \$ Sera reacting with antigens of Coxsackie B type 2,3 , or 4 . $\| 94$ normal subjects and 20 long-standing diabetics. 
diabetes. Types B1 and B3 showed the same tendency to a lesser extent. There were, however, obvious sample differences between the different diabetic groups and controls, the most important being in age, area of origin of patients, and date of serum collection. Separate analyses of these effects showed that they could not be ignored. Antibodies to types B4 and B5 declined steadily throughout life, whereas B3 titres were highest in age group 0-19 years ; B1 titres were highest in age group 20-39 years and in old age; and B2 and B6 showed little variation with age. The prevalence of different virus types varied in different years and areas, and this was reflected in antibody titres. Within individual years antibody titres were influenced by the seasonal incidence of enterovirus infection, peaks occurring about October. Since the diabetic and control groups were not matched for these variables, the validity of direct comparison of crude antibody titres was questionable. A form of analysis was therefore devised which incorporated corrections for some of these variables.

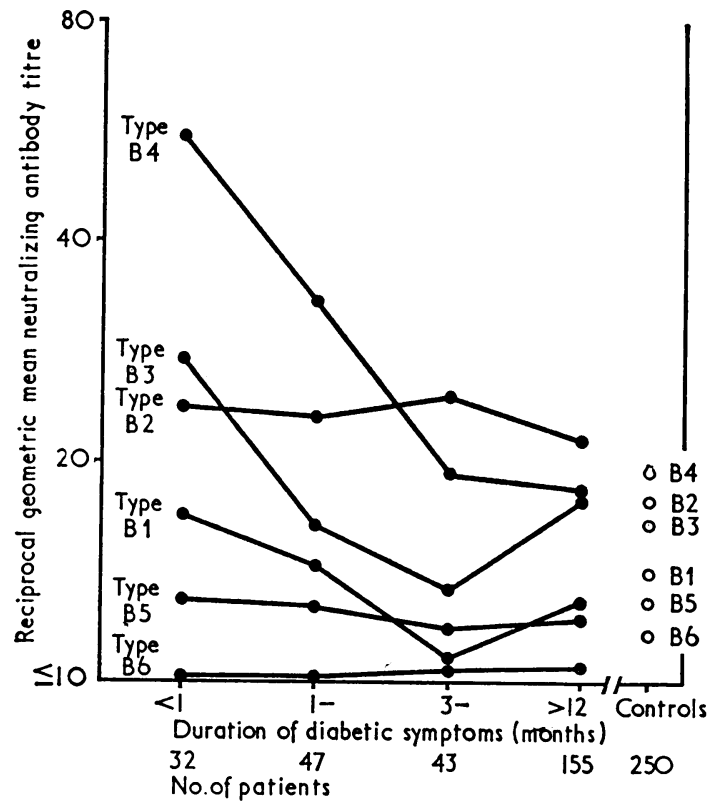

FIG. 1.-Coxsackie B virus neutralizing antibody titres by duration of diabetes (mean uncorrected titres).

The antibody response to primary Coxsackie virus infection is thought to be type-specific, but subsequent infections with other types may elicit heterotypic anamnestic antibody responses which sometimes exceed the homotypic titre (Lennette, Shinomoto, Schmidt, and Magoffin, 1960). A further variable was therefore analysed-namely, the highest titre of each serum against any Coxsackie B type (B max.), which was taken as an index of recent Coxsackie B virus infection, irrespective of type.

On a "null hypothesis" that there was no difference between diabetics and controls, their results for each virus type were pooled and geometric means of log antibody titres were calculated for all patients together ("population mean") and by 10-year age groups (" age group means"). Approximate age corrections were derived by subtracting the population mean from each group mean. All antibody titres were then corrected for age by subtracting the appropriate age correction. With these corrected titres, mean titres were similarly calculated for the five six-month periods covered by the survey in each of the three areas ("time and area means") The deviations of these means from the population means were used as approximate time and area corrections of each patient's crude antibody titres. Thence, by repeating the whole process with the corrected titres, improved estimates of the corrections were derived. After four iterations of this process, subsequent improvement in the corrected titres was less than $1 \%$ of the group means. When both corrections were applied to all antibody titres the recalculated means of both age groups and of time and area groups equalled the population means, thus affording a check on the calculations. This operation was repeated for each Coxsackie B virus type and for the $B$ max. antibody titres.

Some loss of information about differences between diabetics and controls was implicit in this method of correction. In those time and area groups in which there were few controls, high antibody titres of diabetics would be greatly reduced by the corrections which they themselves had largely determined. Moreorer, since the mean titres of diabetics in such groups would ineritably be close to the population means, they could obscure the presence of genuine differences between antibody levels in diabetics and controls. All of the data was therefore utilized to obtain the best estimate of the corrections, but, as few controls were obtained in 1966, only data relating to specimens in 1967 and 1968 were used for the final comparison between diabetics and controls.

Differences were assessed by Student's $t$ test, but the validity of this method is dependent on the data following a multivariate normal distribution. Logarithmic reciprocal antibody titres were approximately normally distributed in groups in which most titres were greater than 1:20-the lowest dilution tested. Since negative sera had to be assigned a numerical value in calculations they were arbitrarily assumed to be positive at $1: 10$. This conventional assumption was essential, but it distorted distributions in groups, including many negative sera. The variance in those groups was restricted, producing a tendency towards a Poisson type of distribution. Some improvement was effected by a square root transformation, and the variable analysed was therefore the square root of the logarithm of the reciprocal antibody titre.

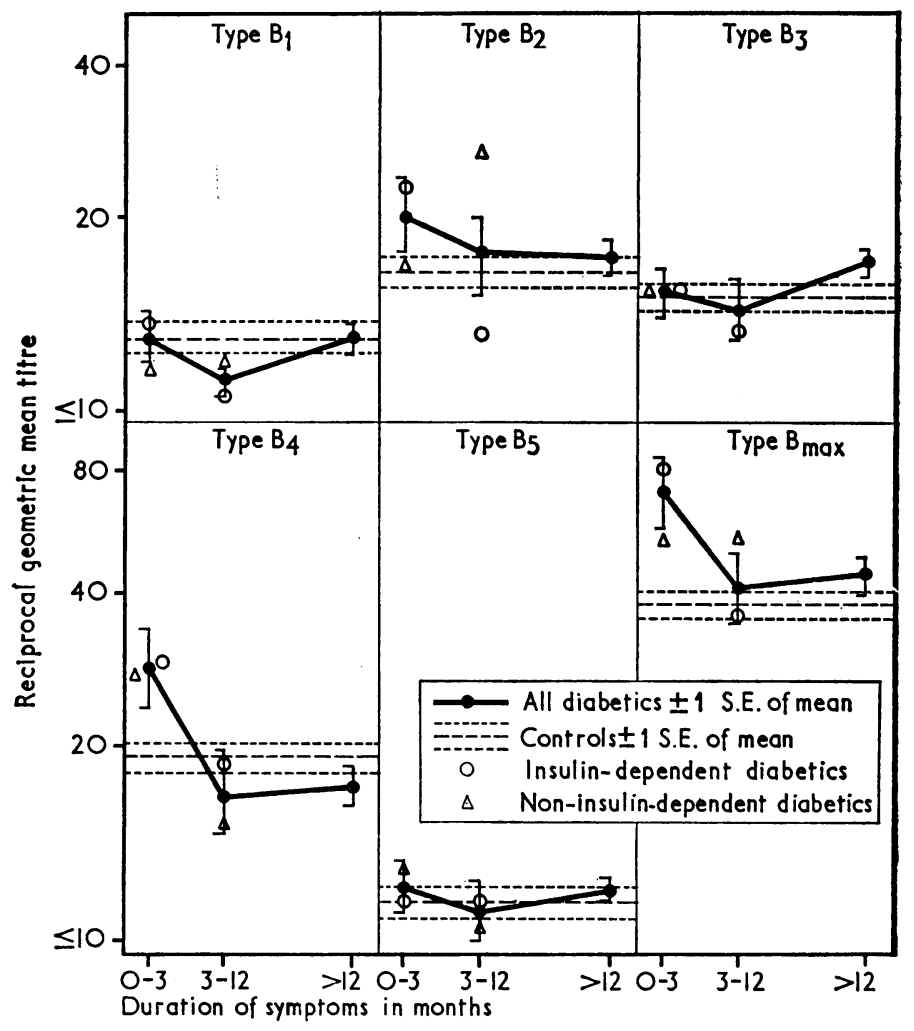

FIg. 2.-Corrected Coxsackie B virus neutralizing antibody titres by duration of diabetes.

The results are shown in Fig. 2. Type B6 antibodies were uncommon and of low titre, and are therefore omitted. Both $\mathrm{B}$ max. and B4 titres were higher in all diabetics within three months of onset than in controls $(P<0.01$ in both instances). Antibody titres in patients seen more than three months from onset were similar to those in controls. Insulin-dependent diabetics within three months of onset also had higher $B$ max. and B4 titres than controls $(P<0.01$ and $P<0.02$ respectively).

Non-insulin-dependent diabetics were a small group which showed no regular pattern.

Although Coxsackie virus neutralizing antibody titres persist for years they may decline more rapidly in the first few months 
following infection than later. The six-month period used for calculating time and area corrections might therefore be too long, and fluctuations in virus prevalence during these periods might be reflected in antibody titres. Collections of serum from both diabetics and controls were clustered in time, and minor epidemics of Coxsackie virus infection were known to have occurred. The corrected B4 and B max. titres of diabetics and controls were therefore examined during shorter calendar periods: two-month periods were used, but where numbers were small adjacent periods were combined (Fig. 3). The titres of both groups reflected the seasonal fluctuations, but the difference between them was maintained over the whole period.

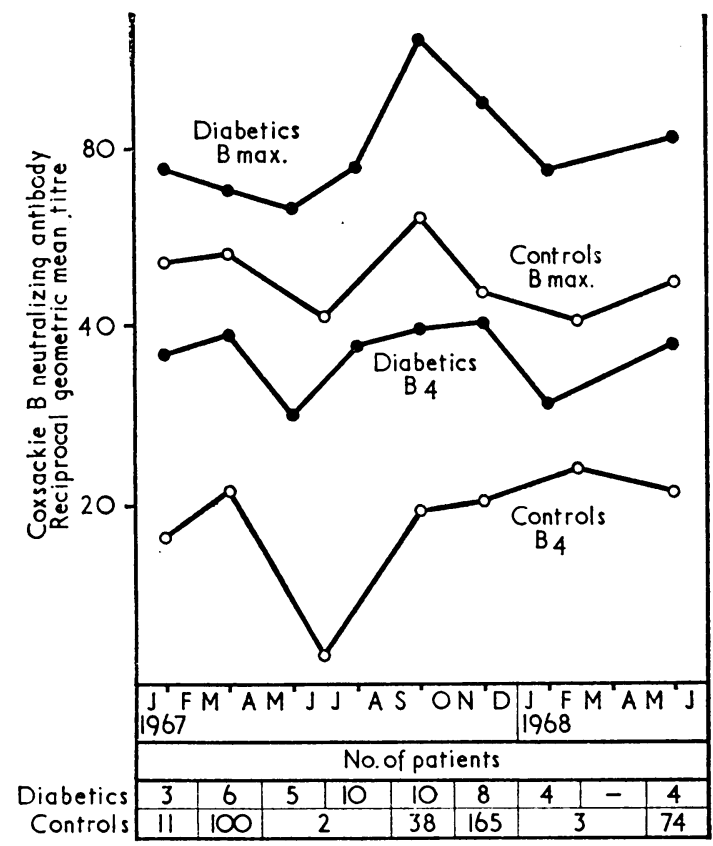

FIG. 3.-Corrected Coxsackie B virus neutralizing antibody titres in diabetics seen within three months of onset of symptoms and controls by two- to four-month periods.

\section{Discussion}

Though the complement-fixing antibody titres were influenced by many uncontrolled factors for which correction was not feasible, several inferences are possible. Firstly, there was no evidence of an excess of recent infection in the diabetics by the common respiratory viruses included in the range of antigens, though it is possible that effects of uncontrolled variables concealed such evidence; the results, however, give no support to the idea that diabetes can be initiated by an excess of winter respiratory infection (Adams, 1926) or to the idea that patients with diabetes of recent onset have a greatly increased susceptibility to virus infection. Secondly, it is clear that in these patients mumps did not commonly precede diabetes. Finally, since more diabetics than controls had Coxsackie B virus antibody, the onset of diabetes could sometimes be associated with infection by Coxsackie B or an antigenically related virus.

The neutralizing antibody titres reported have the advantages of greater specificity and the corrections for age, time, and area of origin of patients, though interactions between those factors are ignored. The high $\mathrm{B}$ max. titres in diabetics within three months of the onset support an association between diabetes and Coxsackie $\mathrm{B}$ virus infection, and the high $\mathrm{B} 4$ titres suggest that this type is most commonly responsible. Types B2 and B4 antibodies were often found together in the same patient, but the high $\mathrm{B} 2$ titres are probably due to anamnestic responses in type B4 infection (Lennette et al., 1960).
The results for the non-insulin-dependent diabetics are irregular and inconclusive, though the high type B4 titres in those seen within three months of onset are of interest.

High mean antibody titres could result from a high proportion of sera with residual antibody due to remote infection or from a smaller proportion with high antibody titres due to recent infection. Residual titres from remote infection decline slowly, and as titres in diabetics between 3 and 12 months from onset were significantly lower than those in diabetics within three months of onset the latter presumably indicate recent infection.

There is little accurate knowledge of the maximal antibody titres attained after Coxsackie virus infection, or of their rate of decline. It is difficult, therefore, to estimate the proportion of diabetics who experienced a Coxsackie $B$ virus infection at or before the onset of diabetes. The majority of patients with Coxsackie B virus infection develop homologous neutralizing antibody, but in a few patients antibody cannot be demonstrated or is present at very low titre (Lennette et al., 1960). Of the 64 insulin-dependent diabetics seen within three months of onset $66 \%$ had antibody titres of $1: 20$ or greater against Coxsackie B4 virus, compared with $40 \%$ of controls. Antibody to other Coxsackie B types was found less frequently and diabetics differed little from controls. These percentages would have probably been higher had sera been tested at a lower dilution, and they suggest that a substantial proportion of these patients-but probably not all of them-had experienced Coxsackie B4 virus infection.

The results suggest, therefore, that in the small group of insulin-dependent diabetics studied there was in some cases a temporal association of Coxsackie B virus infection-probably of type B4-with the onset of diabetes. The possibility that the Coxsackie virus antibodies were induced by an antigenically related virus cannot be excluded, but it is noteworthy that a concurrent investigation (Gamble and Taylor, 1969) by a completely independent epidemiological approach also pointed to the possibility of an association with Coxsackie virus type B4. Furthermore, the few viruses isolated from infants with pancreatitis have almost all been Coxsackie B4 viruses. Individually these findings are not conclusive, but jointly they suggest an association which merits further investigation.

REFERENCES

Adams, S. F. (1926). Archives of Internal Medicine, 37, 861.

Barboni, E., and Manocchio, J. (1962). Archivo Veterinario Italiano, 13, 447 .

Bradstreet, C. M. P., and Taylor, C. E. D. (1962). Monthly Bulletin of the Ministry of Health Laboratory Service, 21, 96.

Craighead, E. (1966). Americain Fournal of Pathology, 48, 333.

Craighead, E., and McLane, M. F. (1968). Science, 162, 913.

Danowski, T. S. (1957). Diabetes Mellitus with Emphasis on Children and Young Adults, p. 129. Baltimore, Williams and Wilkins.

Fechner, R. E., Smith, M. G., and Middelkamp, J. N. (1963). American fournal of Pathology, 42, 493.

Gamble, D. R., and Taylor, K. W. (1969). British Medical fournal,

Hirano, T., and Ruebner, B. H. (1968). Federation Proceedings, 27, 664. Kibrick, S. New England fournal of Medicine, 255, 883 .

Kibrick, S. and Benirschke, K. (1958). Pediatrics, 22, 857.

Lennette, E. H., Shinomoto, T. T., Schmidt, N. J., and Magoffin, R. L. (1960). Fournal of Immunology, 86, 257.

Melnick, J. L., Wenner, H. A., and Rosen, L. (1964). In Diagnostic Procedures for Viral and Rickettsial Diseases, 3rd ed., edited by E. H. Lennette and N. J. Schmidt, p. 235. New York, American

Public Health Association.
Murphy, A. M., and Simmul, R. (1964). Medical fournal of Australia, $2,443$.

Pappenheimer, A. M., Kunz, L. J., and Richardson, S. (1951). Fournal of Experimental Medicine, 94, 45.

Platt, H. (1956). Fournal of Pathology and Bacteriology, 72, 299.

Stang, J. (1864). Cited by E. Gundersen, fournal of Infectious Diseases, $1927,41,197$.

Stanley, N. F., Dorman, D. C., and Ponsford, J. (1953). Australian fournal of Experimental Biology and Medical Science, 31, 147.

Wislocki, L. C. (1966). New England fournal of Medicine, 275, 322.

Wood, E. M., Snieszko, S. F., and Yasutake, W. T. (1955). Archives of Pathology, 60, 26. 